\title{
Nickel versus Palladium in Cross-Coupling Catalysis: On the Role of Substrate Coordination to Zerovalent Metal Complexes
}

\author{
Alasdair K. Cooper ${ }^{\mathrm{a}}$ \\ Paul M. Burton ${ }^{b}$ \\ David J. Nelson*a
}

a WestCHEM Department of Pure and Applied Chemistry, University of Strathclyde, 295 Cathedral Street, Glasgow, G1 1 XL, Scotland

david.nelson@strath.ac.uk

'Syngenta, Jealott's Hill International Research Centre,

Bracknell, Berkshire, RG42 6EY, UK

Dedicated to Gavin Bain on the occasion of his retirement, in acknowledgement of his many years of service within the Department of Pure and Applied Chemistry at the University of Strathclyde.

Published as part of the Bürgenstock Special Section 2019 Future Stars in Organic Chemistry

Received: 17.11.2019

Accepted after revision: 16.12 .2019

Published online: 19.12.2019

DOI: 10.1055/s-0039-1690045; Art ID: ss-2019-z0636-op

Abstract A detailed comparison of the effect of coordinating functional groups on the performance of Suzuki-Miyaura reactions catalysed by nickel and palladium is reported, using competition experiments, robustness screening, and density functional theory calculations. Nickel can interact with a variety of functional groups, which manifests as selectivity in competitive cross-coupling reactions. The presence of these functional groups on exogenous additives has effects on cross-coupling reactions that range from a slight improvement in yield to the complete cessation of the reaction. In contrast, palladium does not interact sufficiently strongly with these functional groups to induce selectivity in cross-coupling reactions; the selectivity of palladium-catalysed crosscoupling reactions is predominantly governed by aryl halide electronic properties.

Key words nickel catalysis, cross-coupling, robustness screening, reaction mechanisms, structure-activity relationships

Palladium-catalysed cross-coupling reactions are amongst the most widely deployed tools in the synthesis of fine chemicals, pharmaceuticals, and agrochemicals, due to their robustness, functional group tolerance, and their ability to use reagents such as boronic acids and boronic esters; these reagents are typically straightforward to prepare on scale and are usually stable under ambient conditions. ${ }^{1-4}$ The development of nickel-catalysed reactions of this type is a subject of much recent research, with a variety of new reactions taking advantage of the different properties of nickel versus palladium. ${ }^{5} \mathrm{~A}$ full and detailed evaluation of the reactivity differences between these two metals is important to understand their capabilities, and to underpin the development of new synthetic chemistry methodology. ${ }^{6}$ It is known that nickel will react with a wide range of substrates $^{7}$ and that nickel(I) intermediates can arise
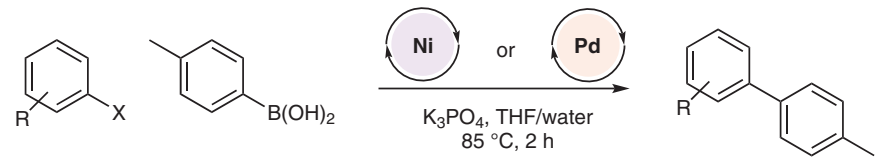

How do functional groups affect selectivity or inhibit reactions?

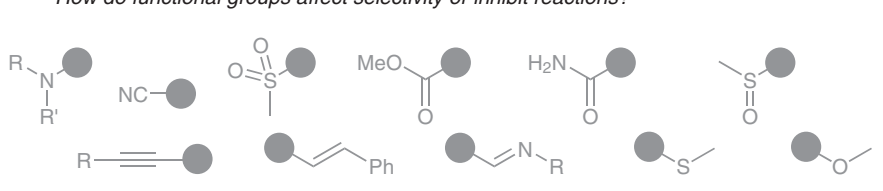

through comproportionation 7,8 or halide abstraction ${ }^{9-12}$ during catalytic reactions. West and Watson have recently conducted a comparative study of nickel- and palladiumdppf complexes in Suzuki-Miyaura reactions. ${ }^{13}$ However, the functional group tolerance of nickel versus palladium catalysis, and the underlying reasons behind why these can differ so much, has not yet been fully and satisfactorily understood.

We have recently disclosed that aldehydes and ketones have a significant influence on the outcomes of nickel-catalysed Suzuki-Miyaura reactions [Scheme 1 (a)]. ${ }^{4}$ When these groups are substituents on the aryl halide, they lead to a significantly enhanced rate of oxidative addition and can be used to enable site-selective catalysis; when these groups are substituents on exogenous additives as part of a robustness screen ${ }^{14}$ they inhibit the catalytic reaction. A series of competition reactions established that aryl halides with aldehyde or ketone (but not ester) substituents will undergo cross-coupling in the presence of other aryl halides that do not have these substituents, to the point that the normal order of reactivity of different organohalides (I > $\mathrm{Br}>\mathrm{Cl}$ ) is overridden.

Here, we report our studies of the analogous palladiumcatalysed reactions, applying our methodology to measure reaction selectivity, and utilising a robustness screen to understand the effects, if any, of a wider range of functional groups on the outcomes of nickel- and palladium-catalysed Suzuki-Miyaura reactions [Scheme 1 (b)].

All reactions were carried out under the conditions in Scheme 2 (a). ${ }^{4}\left[\mathrm{PdCl}_{2}(\mathrm{dppf})\right]$ (1) was used in place of $[\mathrm{NiCl}(0$-tol)(dppf)] (2) for the palladium-catalysed reactions [dppf = 1,1'-bis(diphenylphosphino)ferrocene]; complexes $\mathbf{1}$ and $\mathbf{2}$ often offer comparable reactivity in SuzukiMiyaura reactions..$^{13}$ Our reaction conditions require only a slight excess of boronic acid in order to activate the $\mathrm{M}^{\mathrm{II}}$ 
(a) Carbonyl effects on Ni-catalysed Suzuki-Miyaura reactions
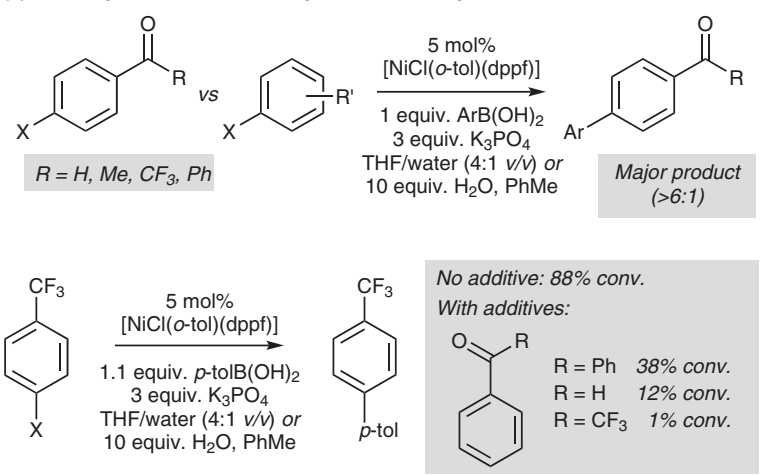

(b) Substituent effects on Pd-catalysed Suzuki-Miyaura reactions (this work)<smiles>Brc1ccccc1</smiles>
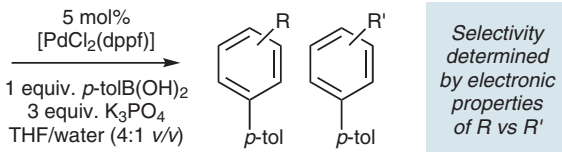<smiles>[X]c1ccc(C(F)(F)F)cc1</smiles>

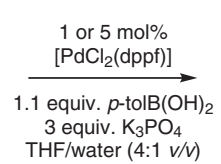<smiles>FC(F)(F)c1ccc(OCCOc2ccccc2)cc1</smiles>

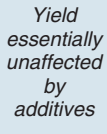

Scheme 1 (a) Previous work in understanding functional group effects on nickel catalysis. (b) A comparison of nickel and palladium.

pre-catalyst via transmetalation and reductive elimination. ${ }^{8}$ The outcomes of the reactions described here were determined using GC-FID analysis with $n$-dodecane as an internal standard; the apparatus was calibrated using authentic samples of each substrate and product, which were used to prepare solutions containing known ratios of substrate to internal standard.

We have previously ${ }^{4}$ conducted competition reactions in both a THF/water $(4: 1 \mathrm{v} / \mathrm{v})$ mixture and in toluene with 10 equivalents of water, which gave comparable results, while robustness screening reactions were performed in toluene; here, all reactions were performed in the THF/water solvent system as this avoids issues with clumping of the base and instead forms a homogeneous biphasic mixture.

Reactions were performed in which 1 equivalent of a substituted aryl bromide $\left(p-\mathrm{YC}_{6} \mathrm{H}_{4} \mathrm{Br}\right.$, S1-S19) and 1 equivalent of bromobenzene competed for 1 equivalent of boronic acid [Scheme 2 (b)]. The conversion to each of the two possible products (P1 to P19 or 4-methylbiphenyl) was quantified by GC-FID analysis, and the resulting data were interpreted using Equation 1, which defines the selectivity for the cross-coupling of the substituted aryl bromide. A value of 1 represents a reaction that is entirely selective for the (a)<smiles>Cc1ccc(Br)cc1</smiles><smiles>Cc1ccc(-c2ccc(C(F)(F)F)cc2)cc1</smiles>

$94 \%$ conversion (calibrated GC-FID analysis)

(b)

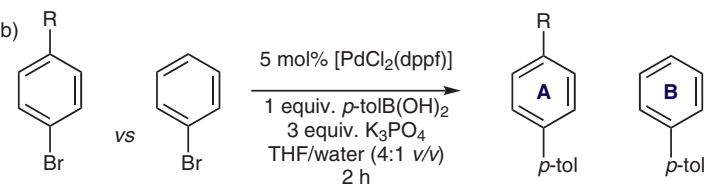

Product ratio determined by calibrated GC-FID analysis

$\mathrm{R}=\mathrm{NMe}_{2}(\mathbf{S} 1), \mathrm{NEt}_{2}(\mathbf{S} 2), \mathrm{NHPh}(\mathbf{S} 3), \mathrm{OMe}(\mathbf{S} 4), i-\operatorname{Pr}(\mathbf{S} 5)$,

$\mathrm{C}(\mathrm{H})=\mathrm{C}(\mathrm{H}) \mathrm{Ph}$ (S6), SMe (S7), CCPh (S8), $\mathrm{OCF}_{2} \mathrm{H}$ (S9), $\mathrm{OCF}_{3}$ (S10),

$\mathrm{CHO}(\mathbf{S} 11), \mathrm{C}(\mathrm{H})=\mathrm{NPh}(\mathbf{S} 12), \mathrm{COPh}$ (S13), $\mathrm{CO}_{2} \mathrm{Me}$ (S14)

SOMe (S15), COMe (S16), $\mathrm{CF}_{3}$ (S17), CN (S18), $\mathrm{SO}_{2} \mathrm{Me}$ (S19)

Scheme 2 Conditions for cross-coupling reactions for (a) single substrates and (b) competition reactions

cross-coupling of $p-\mathrm{YC}_{6} \mathrm{H}_{4} \mathrm{Br}$, and a value of -1 represents a reaction that is entirely selective for the cross-coupling of bromobenzene.

$$
\text { Selectivity }=([\mathbf{A}]-[\mathbf{B}]) /([\mathbf{A}]+[\mathbf{B}])
$$

Equation 1 Measurement of selectivity in competition reactions between an aryl bromide and bromobenzene, yielding products $\mathbf{A}$ and $\mathbf{B}$, respectively

For each competition reaction, the selectivity number was plotted versus $\sigma_{\mathrm{p}}$, which quantifies the net electrondonating or -withdrawing property of substituent Y (Figure $1) ;{ }^{15}$ some of the data have been reported previously, ${ }^{4}$ but this study adds several additional data points. Data points are colour coded according to whether they feature a coordinating $\pi$-system (nitrile, ketone, aldehyde, imine, alkene, alkyne; green points) or not (blue points).

The plot for nickel [Figure 1 (a)] shows a relatively flat profile for the blue points (except $\mathrm{S7}(\mathrm{R}=\mathrm{SMe})$ and $\mathbf{S 1 5}$ $(\mathrm{R}=\mathrm{SOMe})$, showing that selectivity in these reactions is relatively insensitive to the electronic properties of the aryl halide. Species with known coordinating groups such as ketones, aldehydes, nitrile, alkene, and alkynes show enhanced selectivity in these Suzuki-Miyaura reactions. Future work will further investigate the effect of the sulfide and sulfoxide groups on reaction selectivity, as these can potentially coordinate transition metals via the lone pair(s) on the relatively soft sulfur.

The plot for the palladium-catalysed reactions (using 1) is consistent with the accepted trend that electron-poor aryl bromides undergo more rapid oxidative addition than electron-rich aryl bromides [Figure 1 (b)]. ${ }^{16}$ The results here are significantly different from those obtained with nickel 


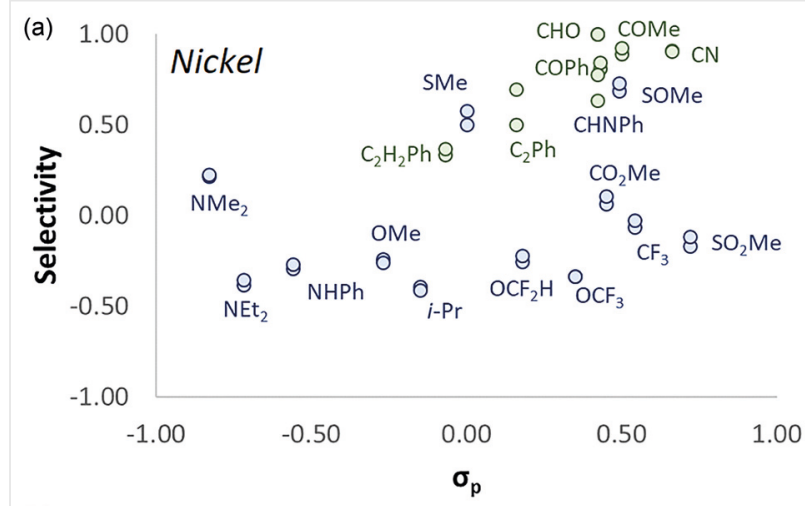

(b)

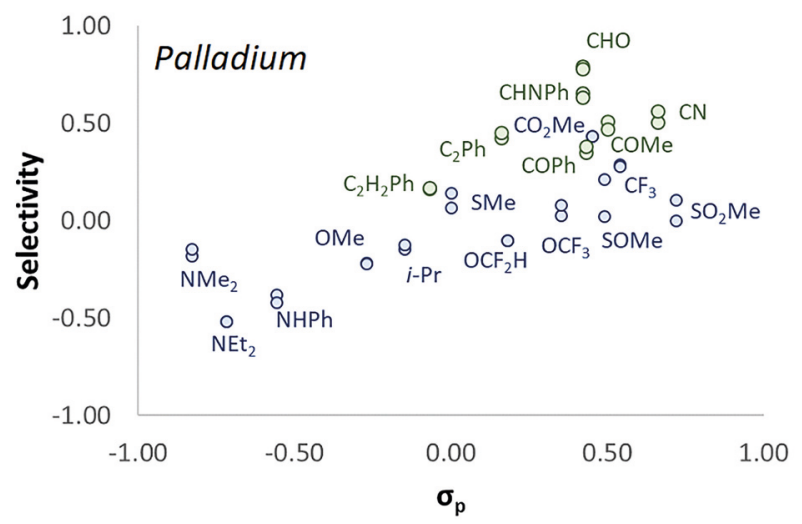

Figure 1 (a) Selectivity data for cross-coupling reactions catalysed by $[\mathrm{NiCl}(0-$ tol)(dppf)] (2). (b) Selectivity data for cross-coupling competition reactions catalysed by $\left[\mathrm{PdCl}_{2}(\mathrm{dppf})\right](\mathbf{1})$. Green points indicate functional groups with potentially coordinating $\pi$-systems, while blue points indicate functional groups without this feature.

catalyst $\mathbf{2}$. The trend is dominated by electronic effects but some selectivity is seen for the functional groups that might coordinate metal centres via a $\pi$-system. These reactions are far less selective than the corresponding nickelcatalysed competition reactions.

These data establish that coordinating functional groups have much less of an effect in palladium catalysis than they do in nickel catalysis, and so a robustness screen ${ }^{14}$ was carried out with additives A1 to $\mathbf{A 1 8}$ to understand whether additives with coordinating functional groups affect the outcomes of prototypical Suzuki-Miyaura reactions (Scheme 3). In these reactions, 1 equivalent of each additive was added to the reaction of $p$-(trifluoromethyl)bromobenzene with $p$-tolylboronic acid. GC-FID analysis was used to quantify the conversion of the reaction; this technique therefore allows us to rapidly assess whether the additive interferes with the reaction. Reactions were initially carried out with $5 \mathrm{~mol} \%$ of $\mathbf{1}$ or $\mathbf{2}$. The results of this robustness screen show little or no inhibition of the palladium-catalysed reactions by most of these additives; in the majority of cases, high $(>90 \%)$ conversions are observed. This is in stark contrast to the results with nickel catalysis, where many functional groups inhibit an otherwise productive cross-coupling reaction. Imines and phenylacetylene also had a significant impact on the outcomes of nickel-catalysed reactions, but stilbene and benzonitrile had only a modest effect. Only phenylacetylene had an impact on the yields of palladium-catalysed reactions. The robustness screen was repeated with only $1 \mathrm{~mol} \%$ of 1 to understand whether this would make the reaction more susceptible to poisoning by additives; this had little impact on the yields of the reactions, generally decreasing them by only a few percent. For the nickel-catalysed reactions, attempts were made to correlate reaction inhibition to selectivity data from Figure 1, but there is no clear correlation here.
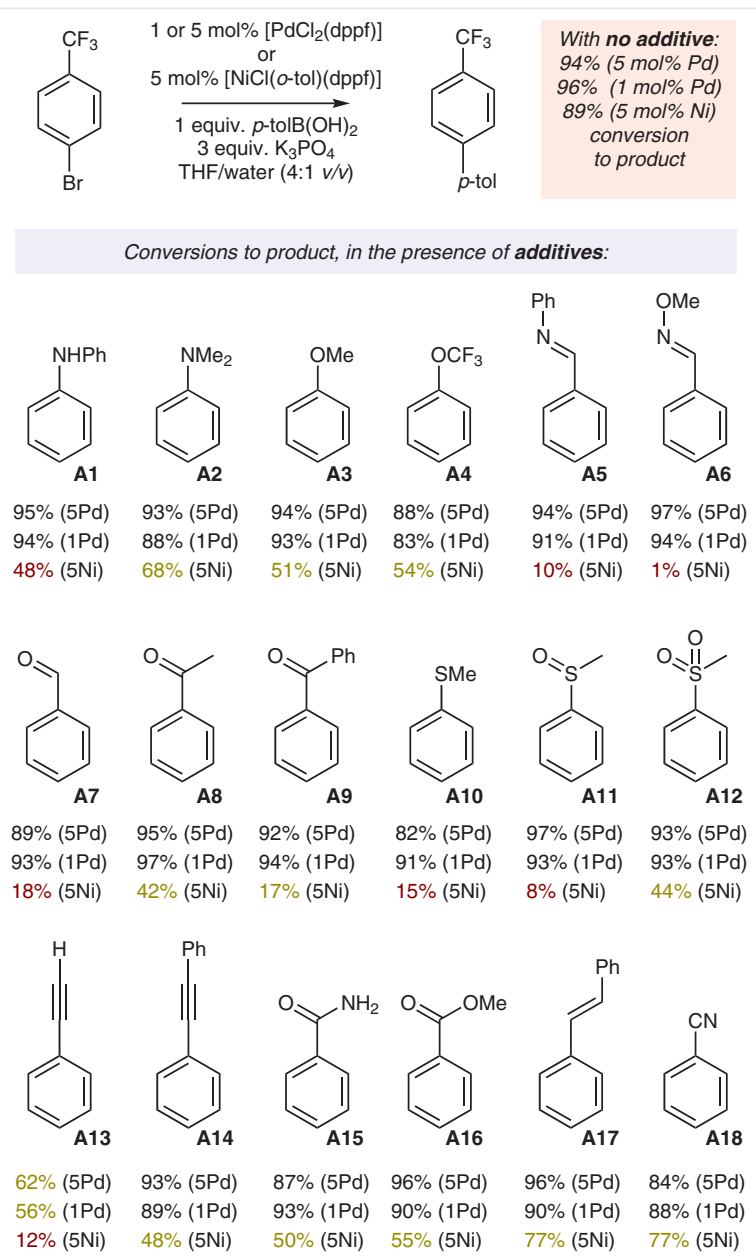

Scheme 3 Outcomes of robustness screening reactions with 1 ( $1 \mathrm{~mol} \%$ or $5 \mathrm{~mol} \%$ ) and 2 ( $5 \mathrm{~mol} \%$ ). Yellow is used to highlight yields between $25 \%$ and $80 \%$, while red is used to highlight yields below $25 \%$. All data are averages of at least two replicates and are obtained from calibrated GC-FID analyses of reaction mixtures, using $n$-dodecane as an internal standard.

These experimental observations were probed further using density functional theory (DFT) calculations. All computational data in this manuscript are reported in THF solu- 


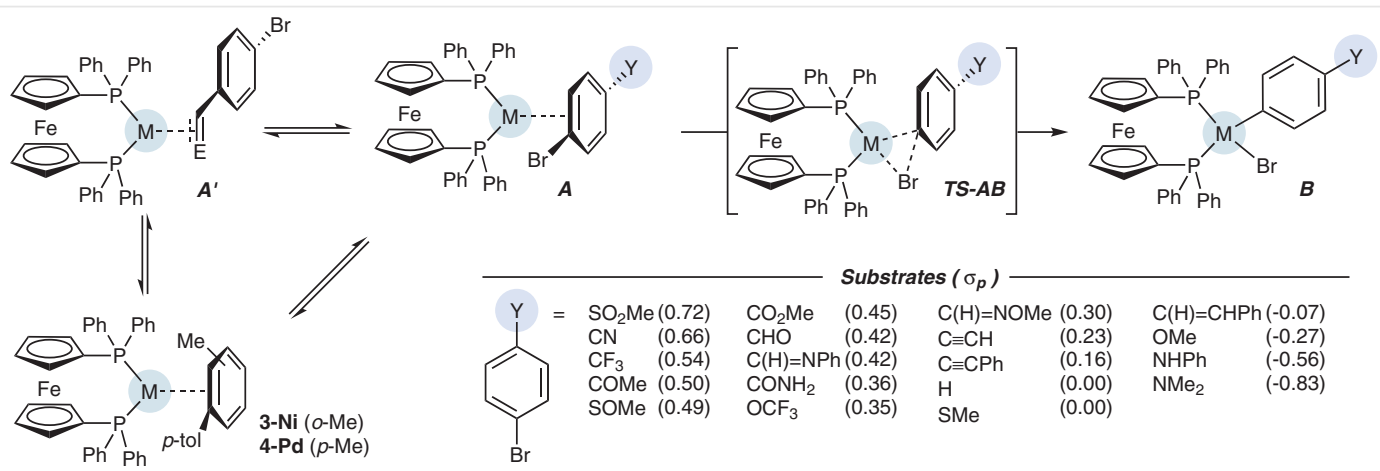

Scheme 4 Structures studied using density functional theory

tion, consistent with experimental work. Complexes $3(\mathrm{Ni})$ and $4(\mathrm{Pd})$ were considered to have $\mathrm{G}_{\mathrm{rel}}=0$, as these are the $\mathrm{M}^{0}$ complexes that will arise from the activation of $\mathbf{2}$ or $\mathbf{1}$, respectively, by transmetalation with $p$-tolylboronic acid (Scheme 4). These arene ligands can be replaced by aryl halide substrates; these can co-ordinate to the metal centre to form an $\eta^{2}$-complex (A), which then undergoes oxidative addition (TS-AB) to form [M( $\mathrm{Ar}) \mathrm{Br}(\mathrm{dppf})]$ (B). Alternatively, some substrates can coordinate to $\mathrm{M}^{0}$ through their functional groups $\left(\mathbf{A}^{\prime}\right)$. The values of interest are (i) the relative energies of $\mathbf{A}$ and $\mathbf{A}^{\prime}$, and (ii) the barrier from $\mathbf{A}$ to $\mathbf{T S}-\mathbf{A B}$ for oxidative addition. If $\mathbf{A}^{\prime}$ is much lower in energy than $\mathbf{A}$ then this might decrease the rate of oxidative addition. The results of these calculations are recorded in Table 1 for both the palladium and the nickel complexes. We did not directly compare the turnover numbers for nickel and palladium; the transmetalation step is not modelled here, as there are multiple possible mechanisms for boronic acid transmetalation. ${ }^{17,18}$ Instead, we have used DFT data to reveal the nature of the competition between the reversible coordination of $\mathrm{M}^{0}$ to functional groups and the (irreversible) oxidative addition step.

Table 1 Free Energies in $\mathrm{kcal} \mathrm{mol}^{-1}$, Relative to Complexes $\mathbf{3}$ (for $\mathrm{Ni}$ ) or $\mathbf{4}$ (for Pd), of the Pre-Oxidative Addition $\eta^{2}$-Complexes (A), the Oxidative Addition Transition State (TS-AB), the Oxidative Addition Product (B), and the $\eta^{2}$-Complex with the Substituent ( $\mathbf{A}^{\prime}$ ) for the Reactions of $\mathbf{3}$ and $\mathbf{4}$ with the Substrates in Scheme 4

\begin{tabular}{|c|c|c|c|c|c|c|c|c|c|c|c|c|}
\hline \multirow[t]{2}{*}{ Y } & \multicolumn{6}{|c|}{ Nickel 3} & \multicolumn{6}{|c|}{ Palladium 4} \\
\hline & A & $\mathbf{A}^{\prime}$ & TS-AB & B & $A$ vs $\mathbf{A}^{\prime a}$ & TS-AB vs A & A & $\mathbf{A}^{\prime}$ & TS-AB & B & $A$ vs $\mathbf{A}^{\prime a}$ & TS-AB vs $A$ \\
\hline $\mathrm{SO}_{2} \mathrm{Me}$ & -9.5 & & -2.8 & -35.0 & & 6.7 & -3.3 & & 6.9 & -27.9 & & 10.2 \\
\hline $\mathrm{CN}$ & -9.5 & -11.1 & -3.6 & -34.9 & 1.5 & 5.9 & -3.0 & 0.9 & 7.9 & -27.4 & -3.9 & 10.9 \\
\hline $\mathrm{CF}_{3}$ & -7.9 & & -1.2 & -33.3 & & 6.7 & -0.3 & & 8.5 & -25.9 & & 8.8 \\
\hline COMe & -9.3 & -12.6 & -2.0 & -33.1 & 3.3 & 7.3 & -2.1 & -0.2 & 8.3 & -26.0 & -1.9 & 10.4 \\
\hline SOMe & -7.4 & & 0.9 & -32.9 & & 8.3 & -0.8 & & 9.1 & -25.8 & & 9.9 \\
\hline $\mathrm{CO}_{2} \mathrm{Me}$ & -7.5 & -3.5 & -1.6 & -32.1 & -4.0 & 5.9 & -1.7 & 4.5 & 8.9 & -25.0 & -6.2 & 10.6 \\
\hline $\mathrm{CHO}$ & -10.3 & -16.0 & -2.6 & -33.5 & 5.7 & 7.7 & -3.0 & -2.5 & 7.9 & -26.0 & -0.5 & 11.0 \\
\hline$C(\mathrm{H})=\mathrm{NHPh}$ & -8.7 & -17.7 & -2.0 & -32.9 & 9.0 & 6.7 & -0.4 & -6.8 & 8.3 & -24.4 & 6.4 & 8.7 \\
\hline $\mathrm{CONH}_{2}$ & -6.6 & 0.4 & -1.9 & -32.2 & -7.0 & 4.7 & -1.1 & 6.6 & 9.2 & -25.7 & -7.6 & 10.3 \\
\hline $\mathrm{OCF}_{3}$ & -6.3 & & -0.8 & -33.1 & & 5.5 & -0.4 & & 9.9 & -26.2 & & 10.3 \\
\hline$C(\mathrm{H})=\mathrm{NOMe}$ & -7.7 & -13.1 & -1.3 & -31.9 & 5.4 & 6.4 & 1.0 & -2.5 & 10.1 & -24.4 & 3.5 & 9.1 \\
\hline $\mathrm{C} \equiv \mathrm{CH}$ & -7.0 & -22.4 & -1.6 & -32.3 & 15.4 & 5.4 & 0.1 & -8.9 & 9.7 & -24.8 & 9.0 & 9.6 \\
\hline $\mathrm{C} \equiv \mathrm{CPh}$ & -6.5 & -23.9 & -1.2 & -31.8 & 17.3 & 5.4 & -0.1 & -9.7 & 9.8 & -24.0 & 9.5 & 9.9 \\
\hline $\mathrm{H}$ & -3.8 & & 1.5 & -30.1 & & 5.2 & 2.4 & & 11.4 & -22.9 & & 9.0 \\
\hline SMe & -5.4 & & 0.7 & -30.6 & & 6.1 & 1.1 & & 10.2 & -22.8 & & 9.1 \\
\hline$C(\mathrm{H})=\mathrm{CHPh}$ & -5.1 & -20.1 & 1.0 & -31.6 & 15.0 & 6.2 & -0.2 & -10.0 & 10.4 & -22.8 & 9.7 & 10.6 \\
\hline OMe & -1.5 & & 2.6 & -28.3 & & 4.2 & 3.3 & & 11.9 & -22.8 & & 8.6 \\
\hline NHPh & -4.7 & & 2.1 & -27.8 & & 6.8 & 1.7 & & 12.5 & -22.4 & & 10.9 \\
\hline $\mathrm{NMe}_{2}$ & -2.0 & & 3.3 & -25.3 & & 5.3 & 3.7 & & 14.0 & -19.9 & & 10.2 \\
\hline
\end{tabular}

${ }^{a}$ Red shading indicates that $\mathbf{A}$ is lower in energy than $\mathbf{A}^{\prime}$. Blue shading indicates that $\mathbf{A}^{\prime}$ is lower in energy than $\mathbf{A}$. 
These data show that the oxidative addition reactions of dppf- $\mathrm{Ni}^{0}$ present much lower barriers and are much more exergonic than those for dppf- $\mathrm{Pd}^{0}$, consistent with established reactivity trends. ${ }^{6}$ Oxidative addition is unlikely to be the rate-determining step in these nickel-catalysed reactions. For nickel, complexes of the form $\mathbf{A}^{\prime}$ are typically much lower in energy than the corresponding complexes of type $\mathbf{A}$, and it is this effect, and a facile 'ring-walking' process that is proposed to lead to the observed selectivity for substrates with coordinating functional groups.,19-22 For those substrates with amide and ester functional groups the pre-oxidative addition complex $\mathbf{A}$ is lower in energy than $\mathbf{A}^{\prime}$. There are unfortunately no clear correlations between the energy of $\mathbf{A}^{\prime}$ and the selectivity of cross-coupling reactions or the degree of reaction inhibition.

For palladium, none of the $\mathbf{A}^{\prime}$ complexes for carbonylcontaining aryl halides were found to be lower in energy than the corresponding pre-oxidative addition $\eta^{2}$-complexes. The coordination of various other functional groups to the $\mathrm{Pd}^{0}$ complex (forming $\mathbf{A}^{\prime}$ ) is often exergonic, but far less so than for nickel. ${ }^{20,23}$ This goes some way to explaining the lack of selectivity in competition experiments and the lack of any significant inhibition by any of these additives in the robustness screening studies. A search of the Cambridge Structural Database reveals only one palladium-ketone complex, but this is in the form of a benzophenone-derived bisphosphine ligand in which the coordination of two phosphines forces the ketone to interact with the $\mathrm{Pd}^{0}$ centre also. ${ }^{24}$ There is one example of a structurally characterised imine complex of $\mathrm{Pd}^{0} .{ }^{25}$

The coordination of aldehydes and ketones to $\mathrm{Ni}^{0}$ has been studied in depth by Love and Kennepohl, using a variety of experimental and computational techniques. ${ }^{26,27}$ All of the $\mathrm{n}^{2}$-complexes $\mathbf{A}^{\prime}$ in this work are square planar; attempts to locate tetrahedral complexes were unsuccessful, with the structure optimising to the square planar geometry in each case. While the strength of coordination of palladium to functional groups is evidently much lower than in the case of nickel, the reasons behind the observed square planar geometry - donation from a bidentate phosphine into the same $d$ orbital used for $d \rightarrow \pi^{*}$ back-bonding are likely to be the same. Several plots were constructed to visualise these differences in behaviour between palladium and nickel. Plots of $G_{\text {rel }}\left(\right.$ TS-AB) versus $\sigma_{\mathrm{p}}$ give reasonably good linear correlations that have very similar slopes for Pd and $\mathrm{Ni}(-4.1$ vs -4.2 ) [Figure 2 (a)]. However, when $\Delta \mathrm{G}^{\ddagger}(\mathbf{A} \rightarrow \mathbf{T S}-\mathbf{A B})$ is plotted versus $\sigma_{\mathrm{p}}$ the plot is almost flat, although there is significant scatter [Figure 2 (b)]; each substituent influences the free energies $\left(G_{\text {rel }}\right)$ of the pre-oxidative addition $\eta^{2}$-complex $\mathbf{A}$ and oxidative addition transition state TS-AB almost equally. These data, combined with the experimental data in Figure 1, suggest that for palladium catalysis the oxidative addition event may be rate-determining, and $\mathbf{T S}-\mathbf{A B}$ may be the turnover-determining transition state. ${ }^{28}$ In contrast, coordination effects clearly dominate in nickel catalysis, with more subtle differences in the electronic properties of the substituents having little effect.

The relative energies of $\mathbf{A}$ versus $\mathbf{A}^{\prime}$ were compared for palladium versus nickel [Figure 2 (c)]. A good linear correlation was obtained, albeit with nickel favouring $\mathbf{A}^{\prime}$ over $\mathbf{A}$ in most cases. This is further evidence of the same interactions at work for both palladium and nickel; these simply manifest less strongly in the case of palladium, leading to the lack of significant engagement of these functional groups with the $\mathrm{Pd}^{0}$ catalyst, and therefore the lack of leverageable selectivity or observable inhibition in catalysis.

While we present a significant experimental and computational dataset that interrogates functional group effects in cross-coupling catalysis, particularly with nickel, a quantitative link and a robust quantitatively predictive model remain to be established. Semi-quantitatively, where complex $\mathbf{A}^{\prime}$ is lower in energy than $\mathbf{A}$ for nickel catalysis, then we would expect selective cross-coupling of the corresponding aryl halide and the inhibition of cross-coupling reactions by an additive featuring this functional group. The same does not hold for palladium: imines, alkynes, and alkenes should show interesting behaviour based on the difference be-
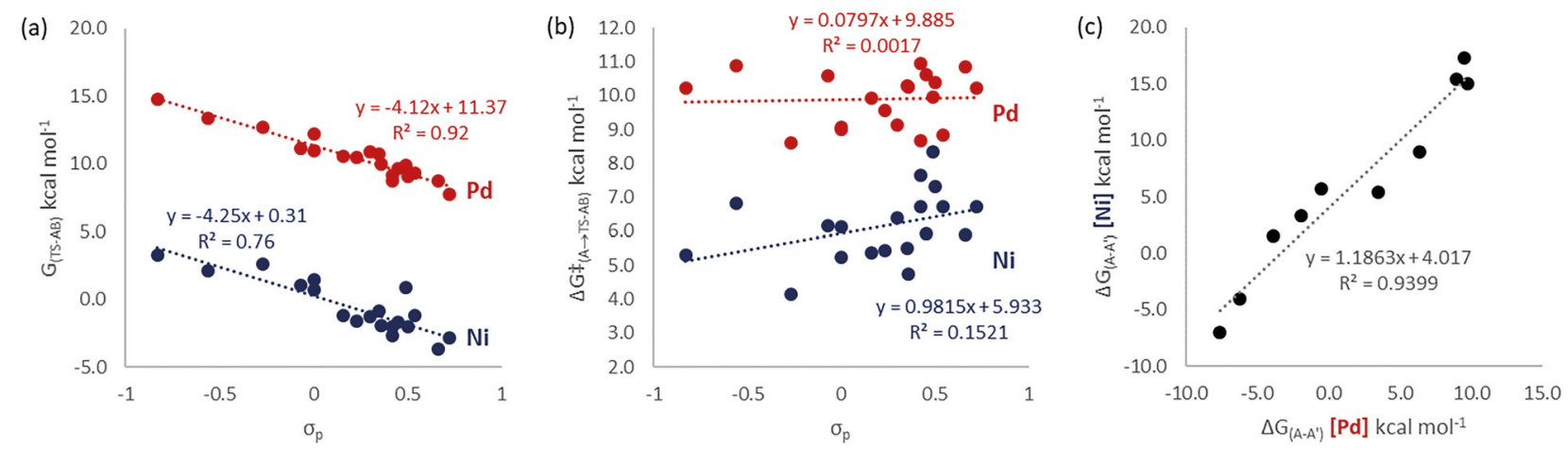

Figure 2 (a) Plot of $G_{\text {rel }}\left(\mathbf{T S}\right.$-AB) versus $\sigma_{p}$ for palladium (red) and nickel (blue). (b) Plot of $\Delta G^{\ddagger}\left(\mathbf{A} \rightarrow \mathbf{T S}\right.$-AB) versus $\sigma_{p}$ for palladium (red) and nickel (blue). (c) Plot of $\Delta \mathrm{G}\left(\mathbf{A}^{\prime}-\mathbf{A}\right)$ for palladium versus $\Delta \mathrm{G}\left(\mathbf{A}^{\prime}-\mathbf{A}\right)$ for nickel. 
tween the energies of $\mathbf{A}$ and $\mathbf{A}^{\prime}$, but experimental observations are limited to some inhibition of catalysis by phenylacetylene. A limitation of our approach here is that we have no time-resolved studies, and so the difference in behaviour may be due to differences in rates or relative rates of key steps.

In conclusion, a detailed and systematic comparison of palladium and nickel and their interactions with potentially coordinating functional groups is reported, and key differences between these two metals are highlighted. Data comprise: measured selectivities from competition experiments; the measurement of the (lack of) inhibition of reactions in which functionalised additives are present; and DFT calculations of the coordination of these functional groups and the oxidative addition pathways of the corresponding aryl bromides. Together, these data show that nickel and palladium interact with functional groups in a considerably different manner. Nickel will strongly interact with many functional groups, resulting in selective crosscoupling reactions, but at the cost of reduced functional group tolerance. Palladium derives no selectivity benefits from these functionalised aryl halides, but therefore shows much better functional group tolerance. This work contributes towards our understanding of cross-coupling catalysis by highlighting differences in the behaviour of palladium and nickel catalysis, and its implications for the application of cross-coupling chemistry in organic synthesis.

Complex 1 was obtained from commercial sources and used as supplied. Complex 2 was prepared according to a literature method. ${ }^{29}$ Most aryl halides (S1-S5, S7-S11, S13, S14, S16-S19) and additives (A1-A5, A7-A10, A12-A16, A18) were obtained from commercial sources and used as supplied; synthetic methods and characterisation data for those that were prepared can be found below or in our previous manuscripts. ${ }^{4,30}$ Samples of most products (P1-P5, P9-P11, P13, P14, P16, P17, P19) were prepared by cross-coupling catalysis, and the data for these are reported below or in our previous study. ${ }^{4}$ Anhydrous, $\mathrm{O}_{2}$-free THF was obtained from an Innovative Technologies PureSolv apparatus. Distilled $\mathrm{H}_{2} \mathrm{O}$ was degassed by sparging with $\mathrm{N}_{2}$ or argon before use. $\mathrm{K}_{3} \mathrm{PO}_{4}$ was obtained from commercial sources, dried overnight in a vacuum oven $\left(50^{\circ} \mathrm{C}\right)$ before use, and stored in a desiccator

NMR spectra were obtained using a Bruker AV3-400 instrument with a liquid $\mathrm{N}_{2}$ Prodigy cryoprobe. ${ }^{1} \mathrm{H}$ NMR spectra are referenced to residual protonated solvent, ${ }^{31}{ }^{13} \mathrm{C}$ NMR spectra are referenced to solvent signals, ${ }^{31}$ and ${ }^{19} \mathrm{~F}$ spectra are externally referenced to $\mathrm{CFCl}_{3}$. GC-MS analyses were performed using an Agilent $7890 \mathrm{~A}$ gas chromatograph fitted with a RESTEK RXi-5Sil column $(30 \mathrm{~m} \times 0.32 \mathrm{~mm}$ I.D. $\times 0.25$ $\mu \mathrm{m})$ and an Agilent 5975C MSD running in EI mode. GC-FID analyses were carried out using an Agilent 7890A gas chromatograph fitted with an Agilent HP5 column ( $30 \mathrm{~m} \times 0.25 \mathrm{~mm}$ I.D. $\times 0.25 \mu \mathrm{m})$.

DFT calculations were carried out in Gaussian 09 (Rev. D.01) $)^{32}$ at the B3LYP level of theory, with Grimme D3 dispersive corrections. ${ }^{33} \mathrm{Ge}-$ ometry optimisations were carried out without symmetry constraints, using the $6-31 \mathrm{G}(\mathrm{d})$ basis set for $\mathrm{H}, \mathrm{C} \mathrm{N}, \mathrm{O}, \mathrm{P}$, and $\mathrm{S}$, the LANL2DZ(dp) basis set and pseudopotential for $\mathrm{Br}$, and the
LANL2TZ(f) basis set and pseudopotential for $\mathrm{Fe}, \mathrm{Ni}$, and Pd. Energies were refined using single point calculations in which $6-311+G(d, p)$ was used for all atoms except $\mathrm{Br}, \mathrm{Fe}, \mathrm{Ni}$, and $\mathrm{Pd}$. Solvation (THF) was applied throughout, using the SMD implicit solvent model. The nature of each stationary point was confirmed using frequency calculations.

\section{Synthetic Cross-Coupling Reactions; General Procedure}

A microwave vial equipped with a stir bar was charged with 4-tolylboronic acid (1.1 mmol, 1.1 equiv.), $\left[\mathrm{PdCl}_{2}(\mathrm{dppf})\right](2)$, and $\mathrm{K}_{3} \mathrm{PO}_{4}(3$ mmol, 3 equiv.). If the aryl halide was a solid, this was charged at this time also ( $1 \mathrm{mmol}, 1$ equiv.). The vial was sealed with a crimp cap and evacuated and backfilled three times with $\mathrm{N}_{2}$ or argon. The vial was then charged with anhyd, $\mathrm{O}_{2}$-free toluene or THF and the aryl halide if liquid ( 1 mmol, 1 equiv.). Degassed $\mathrm{H}_{2} \mathrm{O}$ was also added at this stage, if used. The reaction mixture was stirred for $2 \mathrm{~h}$ at $85^{\circ} \mathrm{C}$, then cooled to r.t., and quenched by piercing the septum. The reaction mixture was filtered through Celite, evaporated to dryness, and purified by column chromatography on silica gel.

\section{Cross-Coupling Competition Reactions; General Procedure}

A microwave vial equipped with a stir bar was charged with 4-tolylboronic acid $\left(0.25 \mathrm{mmol}, 1\right.$ equiv.), $\left[\mathrm{PdCl}_{2}(\mathrm{dppf})\right]$ or $[\mathrm{NiCl}(0$-tol)(dppf)] ( $5 \mathrm{~mol} \%$ ), and $\mathrm{K}_{3} \mathrm{PO}_{4}(0.75 \mathrm{mmol}, 3$ equiv.). If the substituted aryl halide was a solid, this was charged at this time also $(0.25 \mathrm{mmol}$, 1 equiv.). The vial was sealed with a crimp cap and evacuated and backfilled three times with $\mathrm{N}_{2}$ or argon. The vial was then charged with anhyd, $\mathrm{O}_{2}$-free THF $(0.8 \mathrm{~mL})$, bromobenzene $(0.25 \mathrm{mmol}, 1$ equiv.), and the substituted aryl halide if liquid ( $0.25 \mathrm{mmol}, 1$ equiv.). Degassed $\mathrm{H}_{2} \mathrm{O}(0.2 \mathrm{~mL})$ was also added. The reaction was stirred for 2 $\mathrm{h}$ at $85{ }^{\circ} \mathrm{C}$, then cooled to r.t., and quenched by piercing the septum. An accurately-known mass of $n$-dodecane was added, the reaction was mixed, and a sample was taken, filtered, and diluted in $\mathrm{CHCl}_{3}$ for GC analysis.

\section{Robustness Screening; General Procedure}

A microwave vial equipped with a stir bar was charged with 4-tolylboronic acid $\left(0.275 \mathrm{mmol}, 1.1\right.$ equiv.), $\left[\mathrm{PdCl}_{2}(\mathrm{dppf})\right]$ or $[\mathrm{NiCl}(0-$ tol)(dppf)] ( 1 or $5 \mathrm{~mol} \%$ ), and $\mathrm{K}_{3} \mathrm{PO}_{4}(0.75 \mathrm{mmol}, 3$ equiv.). If the additive was a solid, this was charged at this time also $(0.25 \mathrm{mmol}, 1$ equiv.). The vial was sealed with a crimp cap and evacuated and backfilled three times with $\mathrm{N}_{2}$ or argon. The vial was then charged with anhyd, $\mathrm{O}_{2}$-free THF $(0.8 \mathrm{~mL})$, bromobenzene $(0.25 \mathrm{mmol}$, 1 equiv $)$, and the additive if liquid ( $0.25 \mathrm{mmol}, 1$ equiv). Degassed $\mathrm{H}_{2} \mathrm{O}(0.2 \mathrm{~mL})$ was also added. The reaction mixture was stirred for $2 \mathrm{~h}$ at $85^{\circ} \mathrm{C}$ then cooled to r.t. and quenched by piercing the septum. An accuratelyknown mass of $n$-dodecane was added, the reaction was mixed, and a sample was taken, filtered, and diluted in $\mathrm{CHCl}_{3}$ for $\mathrm{GC}$ analysis.

\section{(E)-1-Bromo-4-styrylbenzene (S6)}

Benzyltriphenylphosphonium chloride $(2.547 \mathrm{~g}, 6.6 \mathrm{mmol})$ was added to a $100 \mathrm{~mL}$ round-bottomed flask equipped with a stirrer bar. A suspension of $\mathrm{LiOH} \cdot \mathrm{H}_{2} \mathrm{O}(0.370 \mathrm{~g}, 8.7 \mathrm{mmol})$ in $i-\mathrm{PrOH}(50 \mathrm{~mL})$ was added and the mixture was stirred at r.t. for $20 \mathrm{~min}$. 4-Bromobenzaldehyde ( $1.003 \mathrm{~g}, 6.2 \mathrm{mmol}$ ) was added and the reaction mixture was stirred at reflux for $16 \mathrm{~h}$. Once cooled to r.t., the reaction mixture was extracted with EtOAc $(75 \mathrm{~mL})$ and washed with brine $(75 \mathrm{~mL})$. The organic phase was dried $\left(\mathrm{MgSO}_{4}\right)$, filtered, and evaporated under reduced pressure. The product was recrystallised from $\mathrm{EtOH}$ to give a white powder; yield: $1.103 \mathrm{~g}(67 \%) ; \mathrm{mp} 138-140{ }^{\circ} \mathrm{C}$.

IR (ATR, neat): 3014, 1999, $1493 \mathrm{~cm}^{-1}$. 
${ }^{1} \mathrm{H} \mathrm{NMR}\left(\mathrm{CDCl}_{3}, 400 \mathrm{MHz}\right): \delta=7.70-7.54(\mathrm{~m}, 4 \mathrm{H}, \mathrm{Ar} \mathrm{CH}), 7.41-7.37$ $(\mathrm{m}, 4 \mathrm{H}, \mathrm{Ar} \mathrm{CH}), 7.31(\mathrm{~d}, J=7.0 \mathrm{~Hz}, 1 \mathrm{H}, \mathrm{ArCH}), 7.13(\mathrm{~d}, J=16.7 \mathrm{~Hz}, 1 \mathrm{H}$, $\mathrm{CH}=\mathrm{CH}), 7.06(\mathrm{~d}, J=16.7 \mathrm{~Hz}, 1 \mathrm{H}, \mathrm{CH}=\mathrm{CH})$.

${ }^{13} \mathrm{C}\left\{{ }^{1} \mathrm{H}\right\}$ NMR $\left(\mathrm{CDCl}_{3}, 101 \mathrm{MHz}\right): \delta=136.5,135.8,131.3,128.9,128.3$, $127.5,127.4,126.9,126.1,120.8$.

MS (GC-MS, EI): $m / z=258[\mathrm{M}]^{+}$.

\section{(E)-1-(4-Bromophenyl)- $\mathrm{N}$-phenylmethanimine (S12)}

4-Bromobenzaldehyde (501.2 $\mathrm{mg}, 2.7 \mathrm{mmol}$ ) was added to a microwave vial equipped with a stirrer bar and molecular sieves. The vial was closed using a septum-fitted crimp cap and purged and backfilled with $\mathrm{N}_{2}$. Aniline $(0.246 \mathrm{~mL}, 2.7 \mathrm{mmol}, 1$ equiv.) and anhyd toluene $(2.5 \mathrm{~mL})$ were added and the mixture was heated using microwave irradiation at $200{ }^{\circ} \mathrm{C}$ for $4 \mathrm{~h}$. Once cooled to r.t., the reaction mixture was extracted with $\mathrm{H}_{2} \mathrm{O}(150 \mathrm{~mL})$ and $\mathrm{Et}_{2} \mathrm{O}(3 \times 50 \mathrm{~mL})$. The organic layers were combined, dried $\left(\mathrm{MgSO}_{4}\right)$, and filtered. The solvent was removed under reduced pressure and the product was recrystallised from DCM/pentane to give a yellow amorphous solid; yield: $100.3 \mathrm{mg}$ (14\%).

IR (ATR, neat): 3040, 2880, 1904, 1622, 1584, 1564, 1501, $1485 \mathrm{~cm}^{-1}$. ${ }^{1} \mathrm{H}$ NMR $\left(\mathrm{CD}_{3} \mathrm{CN}, 400 \mathrm{MHz}\right): \delta=8.55(\mathrm{~s}, 1 \mathrm{H}, \mathrm{CHN}), 7.88-7.84(\mathrm{~m}, 2 \mathrm{H}$, Ar CH), 7.72-7.70 (m, 2 H, Ar CH), 7.47-7.43 (m, 2 H, Ar CH), 7.29$7.26(\mathrm{~m}, 2 \mathrm{H}, \mathrm{ArCH}), 7.23(\mathrm{~d}, J=6.1 \mathrm{~Hz}, 1 \mathrm{H}, \mathrm{Ar} \mathrm{CH})$.

${ }^{13} \mathrm{C}\left\{{ }^{1} \mathrm{H}\right\}$ NMR $\left(\mathrm{CD}_{3} \mathrm{CN}, 101 \mathrm{MHz}\right): \delta=158.8,131.5,129.7,129.5,128.8$, 125.7, 124.7, 120.6, 120.4 .

MS (GC-MS, EI): $m / z=259.0[\mathrm{M}]^{+}$.

\section{1-Bromo-4-(methylsulfinyl)benzene (S15)}

4-Bromothioanisole ( $998.6 \mathrm{mg}, 4.9 \mathrm{mmol}$ ) was added to a $100 \mathrm{~mL}$ round-bottomed flask equipped with a stirrer bar and dissolved in DCM $(20 \mathrm{~mL})$. A solution of $m$ CPBA $(1.593 \mathrm{~g}, 1.2$ equiv.) in DCM (10 $\mathrm{mL}$ ) was added to the solution at $0{ }^{\circ} \mathrm{C}$ over $5 \mathrm{~min}$, and the reaction mixture was stirred at r.t. for $12 \mathrm{~h}$. The reaction mixture was diluted with sat. aq $\mathrm{NaHCO}_{3}(100 \mathrm{~mL})$ and extracted with $\mathrm{DCM}(2 \times 50 \mathrm{~mL})$. The organic layers were combined, dried $\left(\mathrm{MgSO}_{4}\right)$, and filtered. The solvent was removed under reduced pressure and the product was recrystallised from DCM/hexane to give a white solid; yield: $472.0 \mathrm{mg}$ (47\%); mp 80-82 ${ }^{\circ} \mathrm{C}$.

IR (ATR, neat): 2990, 2911, 1570, $1470 \mathrm{~cm}^{-1}$.

${ }^{1} \mathrm{H} \mathrm{NMR}\left(\mathrm{CDCl}_{3}, 400 \mathrm{MHz}\right): \delta=7.70(\mathrm{~d}, J=8.1 \mathrm{~Hz}, 2 \mathrm{H}, \mathrm{Ar} \mathrm{CH}), 7.5(\mathrm{~d}$, $J=8.4 \mathrm{~Hz}, 2 \mathrm{H}, \mathrm{Ar} \mathrm{CH}), 2.74\left(\mathrm{~s}, 3 \mathrm{H}, \mathrm{CH}_{3}\right)$.

${ }^{13} \mathrm{C}\left\{{ }^{1} \mathrm{H}\right\}$ NMR $\left(\mathrm{CDCl}_{3}, 101 \mathrm{MHz}\right): \delta=144.4,132.1,125.0,124.7,43.5$.

Analytical data are consistent with the literature. ${ }^{34}$

\section{(E)-4-Methyl-4'-styryl-1,1-biphenyl (P6)}

Synthesised according to the general procedure for synthetic crosscoupling reactions using (E)-1-bromo-4-styrylbenzene (259.5 mg, 1 mmol), 4-tolylboronic acid (149.2 mg, $1.1 \mathrm{mmol}$ ), 2 (6.8 mg, $1 \mathrm{~mol} \%$ ), and $\mathrm{K}_{3} \mathrm{PO}_{4}(635.7 \mathrm{mg}, 3 \mathrm{mmol})$ in a $4: 1(v / v) \mathrm{THF} / \mathrm{H}_{2} \mathrm{O}$ mixture $(2 \mathrm{~mL})$. The desired product was purified by recrystallisation from hexane/DCM to yield a white solid; yield: $251.9 \mathrm{mg}$ (93\%); mp 226$228^{\circ} \mathrm{C}$.

IR (ATR, neat): 3021, 2914, 2046, 1755, 1578, $1493 \mathrm{~cm}^{-1}$.

${ }^{1} \mathrm{H} \mathrm{NMR}\left(\mathrm{CDCl}_{3}, 400 \mathrm{MHz}\right): \delta=7.61(\mathrm{~s}, 4 \mathrm{H}, \mathrm{ArCH}), 7.56-7.54(\mathrm{~m}, 4, \mathrm{Ar}$ $\mathrm{CH}), 7.41-7.38(\mathrm{~m}, 2, \mathrm{Ar} \mathrm{CH}), 7.27(\mathrm{~s}, 1 \mathrm{H}, \mathrm{Ar} \mathrm{CH}), 7.17(\mathrm{~s}, 2 \mathrm{H}, \mathrm{CH})$, $2.43\left(\mathrm{CH}_{3}\right)$.
MS (GC-MS, EI): $m / z=270.1[\mathrm{M}]^{+}$.

Analytical data are consistent with the literature. ${ }^{35}$

\section{Methyl(4'-methyl-[1,1'-biphenyl]-4-yl)sulfane (P7)}

Synthesised according to the general procedure for synthetic crosscoupling reactions using 4-bromothioanisole $(203.8 \mathrm{mg}, 1 \mathrm{mmol})$, 4-tolylboronic acid (148.5 mg, $1.1 \mathrm{mmol}), 2(7.1 \mathrm{mg}, 1 \mathrm{~mol} \%)$, and $\mathrm{K}_{3} \mathrm{PO}_{4}(636.9 \mathrm{mg}, 3 \mathrm{mmol})$ in a $4 / 1(v / v) \mathrm{THF} / \mathrm{H}_{2} \mathrm{O}$ mixture $(2 \mathrm{~mL})$. The desired product was purified by recrystallisation from hexane/DCM to yield a white solid; yield: $171.2 \mathrm{mg}$ (80\%); $\mathrm{mp} 120-122^{\circ} \mathrm{C}$.

${ }^{1} \mathrm{H}$ NMR $\left(\mathrm{CDCl}_{3}, 400 \mathrm{MHz}\right): \delta=7.55-7.49(\mathrm{~m}, 4 \mathrm{H}, \mathrm{Ar} \mathrm{CH}), 7.35(\mathrm{~d}$, $J=9.1 \mathrm{~Hz}, 2 \mathrm{H}, \mathrm{ArCH}), 7.27(\mathrm{~d}, J=9.1 \mathrm{~Hz}, 2 \mathrm{H}, \mathrm{ArCH}), 2.55(\mathrm{~s}, 3 \mathrm{H}$, $\left.\mathrm{SCH}_{3}\right), 2.42\left(\mathrm{~s}, 3 \mathrm{H}, \mathrm{ArCH}_{3}\right)$.

${ }^{13} \mathrm{C}\left\{{ }^{1} \mathrm{H}\right\}$ NMR $\left(\mathrm{CDCl}_{3}, 101 \mathrm{MHz}\right): \delta=137.6(\mathrm{Ar} \mathrm{C}), 137.2(\mathrm{Ar} \mathrm{C}), 136.7$ ( $\mathrm{ArC}), 136.5(\mathrm{ArC}), 129.0(\mathrm{ArCH}), 126.8(\mathrm{Ar} \mathrm{CH}), 126.6(\mathrm{ArCH}), 126.2$ $(\mathrm{Ar} \mathrm{CH}), 20.6\left(\mathrm{SCH}_{3}\right), 15.5\left(\mathrm{ArCH}_{3}\right)$.

MS (GC-MS, EI): $m / z=214.1[\mathrm{M}]^{+}$.

\section{4-Methyl-4'-(phenylethynyl)-1,1'-biphenyl (P8)}

Synthesised according to the general procedure for synthetic crosscoupling reactions using 1-bromo-4-(phenylethynyl)benzene (257.4 $\mathrm{mg}, 1 \mathrm{mmol}$ ), 4-tolylboronic acid (149.3 mg, $1.1 \mathrm{mmol}), 2$ (7.4 mg, 1 $\mathrm{mol} \%)$, and $\mathrm{K}_{3} \mathrm{PO}_{4}(638.1 \mathrm{mg}, 3 \mathrm{mmol})$ in anhyd toluene $(2 \mathrm{~mL})$. The desired product was purified by passing the reaction mixture through a pad of silica gel and evaporating the solvent under reduced pressure to yield a white solid; yield: $141.2 \mathrm{mg}(53 \%) ; \mathrm{mp} 160-162{ }^{\circ} \mathrm{C}$.

IR (ATR, neat): $3021,1578,1493 \mathrm{~cm}^{-1}$.

${ }^{1} \mathrm{H}$ NMR $\left(\mathrm{CDCl}_{3}, 400 \mathrm{MHz}\right): \delta=7.65-7.58(\mathrm{~m}, 6 \mathrm{H}, \mathrm{ArCH}), 7.56(\mathrm{~d}$, $J=8.1 \mathrm{~Hz}, 2 \mathrm{H}, \mathrm{ArCH}), 7.42-7.37(\mathrm{~m}, 3 \mathrm{H}, \mathrm{ArCH}), 7.30(\mathrm{~d}, J=7.8 \mathrm{~Hz}, 2$ $\mathrm{H}, \mathrm{Ar} \mathrm{CH}), 2.44\left(\mathrm{~s}, 3 \mathrm{H}, \mathrm{CH}_{3}\right)$.

${ }^{13} \mathrm{C}\left\{{ }^{1} \mathrm{H}\right\} \operatorname{NMR}\left(\mathrm{CDCl}_{3}, 101 \mathrm{MHz}\right): \delta=140.4(\mathrm{ArC}), 137.02(\mathrm{ArC}), 136.99$ ( $\mathrm{ArC}), 131.5$ ( $\mathrm{Ar} \mathrm{CH}), 131.1(\mathrm{Ar} \mathrm{CH}), 129.1(\mathrm{Ar} \mathrm{CH}), 127.9(\mathrm{Ar} \mathrm{CH})$, 127.7 ( $\mathrm{A} \mathrm{r} \mathrm{C}), 126.4(\mathrm{Ar} \mathrm{CH}), 126.3(\mathrm{Ar} \mathrm{CH}), 122.9(\mathrm{Ar} \mathrm{C}), 121.4(\mathrm{Ar} \mathrm{C})$, $89.5(\mathrm{C} \equiv \mathrm{C}), 88.9(\mathrm{C} \equiv \mathrm{C}), 20.6\left(\mathrm{CH}_{3}\right)$.

MS (GC-MS, EI): $m / z=268.1[\mathrm{M}]^{+}$.

Analytical data are consistent with the literature. ${ }^{36}$

\section{(E)-1-(4'-Methyl-[1,1'-biphenyl]-4-yl)-N-phenylmethanimine (P12)}

Synthesised according to the general procedure for synthetic crosscoupling reactions using (E)-1-(4-bromophenyl)- $N$-phenylmethanimine (261.0 mg, $1 \mathrm{mmol})$, 4-tolylboronic acid (149.4 mg, $1.1 \mathrm{mmol}$ ), $2(7.2 \mathrm{mg}, 1 \mathrm{~mol} \%)$, and $\mathrm{K}_{3} \mathrm{PO}_{4}(637.1 \mathrm{mg}, 3 \mathrm{mmol})$ in a $4: 1(v / v)$ $\mathrm{THF} / \mathrm{H}_{2} \mathrm{O}$ mixture $(2 \mathrm{~mL})$. The desired product was purified by recrystallisation from hexane/DCM to yield a pale orange/brown solid; yield: $225.1 \mathrm{mg}(83 \%) ; \mathrm{mp} 134-136{ }^{\circ} \mathrm{C}$.

IR (ATR, neat): 3048, 2976, 2355, $1531 \mathrm{~cm}^{-1}$.

${ }^{1} \mathrm{H}$ NMR $\left(\mathrm{CD}_{3} \mathrm{CN}, 400 \mathrm{MHz}\right): \delta=8.61(\mathrm{~s}, 1 \mathrm{H}, \mathrm{CHN}), 8.00(\mathrm{~d}, J=8.1 \mathrm{~Hz}, 2$ $\mathrm{H}, \mathrm{ArCH}), 7.79$ (d, J=8.1 Hz, $2 \mathrm{H}, \mathrm{ArCH}), 7.64(\mathrm{~d}, J=8.1 \mathrm{~Hz}, 2 \mathrm{H}, \mathrm{Ar}$ $\mathrm{CH}), 7.46(\mathrm{t}, J=8.6 \mathrm{~Hz}, 2 \mathrm{H}, \mathrm{Ar} \mathrm{CH}), 7.34(\mathrm{~d}, J=8.6 \mathrm{~Hz}, 2 \mathrm{H}, \mathrm{Ar} \mathrm{CH})$, 7.29-7.27 (m, $3 \mathrm{H}, \mathrm{ArCH}$ ), 2.42 (s, $3 \mathrm{H}, \mathrm{CH}_{3}$ ).

${ }^{13} \mathrm{C}\left\{{ }^{1} \mathrm{H}\right\}$ NMR $\left(\mathrm{CD}_{3} \mathrm{CN}, 101 \mathrm{MHz}\right): \delta=159.6,151.6,143.1,137.6,136.5$, 134.8, 129.2, 128.8, 128.7, 126.6, 126.4, 125.5, 120.4, 19.7.

MS (GC-MS, EI): $m / z=268.1[\mathrm{M}]^{+}$. 


\section{4-Methyl-4'-(methylsulfinyl)-1,1'-biphenyl (P15)}

Synthesised according to the general procedure for synthetic crosscoupling reactions using 1-bromo-4-(methylsulfinyl)benzene (218.4 $\mathrm{mg}, 1 \mathrm{mmol})$, 4-tolylboronic acid (147.1 mg, $1.1 \mathrm{mmol}), 2$ (7.5 mg, 1 mol\%), and $\mathrm{K}_{3} \mathrm{PO}_{4}(633.1 \mathrm{mg}, 3 \mathrm{mmol})$ in a $4: 1(v / v) \mathrm{THF} / \mathrm{H}_{2} \mathrm{O}$ mixture $(2 \mathrm{~mL})$. The desired product was purified by passing through a silica gel plug and eluting with hexane, then EtOAc, then $\mathrm{MeOH}$ to yield a white solid; yield: $105.3 \mathrm{mg}$ (46\%); mp $140-142^{\circ} \mathrm{C}$.

${ }^{1} \mathrm{H} \mathrm{NMR}\left(\mathrm{CDCl}_{3}, 400 \mathrm{MHz}\right): \delta=7.74(\mathrm{~d}, J=8.3 \mathrm{~Hz}, 4 \mathrm{H}, \mathrm{Ar} \mathrm{CH}), 7.53(\mathrm{~d}$, $J=7.5 \mathrm{~Hz}, 2 \mathrm{H}, \mathrm{ArCH}), 7.30(\mathrm{~d}, J=8.3 \mathrm{~Hz}, 2 \mathrm{H}, \mathrm{ArCH}), 2.79\left(\mathrm{~s}, 3 \mathrm{H}, \mathrm{CH}_{3}\right)$, $2.44\left(\mathrm{~s}, 3 \mathrm{H}, \mathrm{CH}_{3}\right)$.

${ }^{13} \mathrm{C}\left\{{ }^{1} \mathrm{H}\right\}$ NMR $\left(\mathrm{CDCl}_{3}, 101 \mathrm{MHz}\right): \delta=143.7,143.6,137.6,136.4,129.2$, 127.4, 126.6, 123.6, 43.6, 20.6.

MS (GC-MS, EI): $m / z=230.1[\mathrm{M}]^{+}$.

\section{4'-Methyl-[1,1'-biphenyl]-4-carbonitrile (P18)}

Synthesised according to the general procedure for synthetic crosscoupling reactions using 4-bromobenzonitrile ( $182.0 \mathrm{mg}, 1 \mathrm{mmol}$ ), 4-tolylboronic acid (148.4 mg, $1.1 \mathrm{mmol}), 2$ (7.2 mg, $1 \mathrm{~mol} \%)$, and $\mathrm{K}_{3} \mathrm{PO}_{4}(634.2 \mathrm{mg}, 3 \mathrm{mmol})$ in anhyd toluene $(2 \mathrm{~mL})$. The desired product was purified by flash column chromatography on silica gel using $5 \%$ EtOAc/hexane $\left(R_{f}=0.32\right)$ to yield a white solid; yield: $148.5 \mathrm{mg}$ (77\%); mp $110-112{ }^{\circ} \mathrm{C}$.

IR (ATR, neat): 3464, 3055, 2995, 1709, 1582, $1476 \mathrm{~cm}^{-1}$.

${ }^{1} \mathrm{H} \mathrm{NMR}\left(\mathrm{CDCl}_{3}, 400 \mathrm{MHz}\right): \delta=7.73(\mathrm{~d}, J=8.3 \mathrm{~Hz}, 2 \mathrm{H}, \mathrm{ArCH}), 7.69$ (d, $J=8.3 \mathrm{~Hz}, 2 \mathrm{H}, \mathrm{ArCH}), 7.52(\mathrm{~d}, J=8.0 \mathrm{~Hz}, 2 \mathrm{H}, \mathrm{ArCH}), 7.32$ (d, $J=8.2$ $\mathrm{Hz}, 2 \mathrm{H}, \mathrm{Ar} \mathrm{CH}), 2.45\left(\mathrm{~s}, 3 \mathrm{H}, \mathrm{CH}_{3}\right)$.

${ }^{13} \mathrm{C}\left\{{ }^{1} \mathrm{H}\right\}$ NMR $\left(\mathrm{CDCl}_{3}, 101 \mathrm{MHz}\right): \delta=145.1,138.3,135.8,132.1(2 \mathrm{C})$, 129.4 (2 C), 127.0 (2 C), 126.6 (2 C), 118.5, 110.1, 20.7.

MS (GC-MS, EI): $m / z=193.1[\mathrm{M}]^{+}$.

Analytical data are consistent with the literature. ${ }^{37}$

\section{(E)-Benzaldehyde 0 -Methyl Oxime (A6)}

Methoxyamine hydrochloride ( $231.4 \mathrm{mg}, 2.7 \mathrm{mmol}$ ) was added to a microwave vial equipped with a stirrer bar and molecular sieves. The vial was closed using a septum-fitted crimp cap and purged and backfilled with $\mathrm{N}_{2}$. Benzaldehyde $(0.276 \mathrm{~mL}, 2.7 \mathrm{mmol}, 1$ equiv.), pyridine $(0.220 \mathrm{~mL}, 2.7 \mathrm{mmol}, 1$ equiv.), and anhyd toluene $(2.5 \mathrm{~mL})$ were added and the mixture was heated using microwave irradiation at $200{ }^{\circ} \mathrm{C}$ for $4 \mathrm{~h}$. Once cooled to r.t., the reaction mixture was extracted with $\mathrm{H}_{2} \mathrm{O}(150 \mathrm{~mL})$ and $\mathrm{Et}_{2} \mathrm{O}(3 \times 50 \mathrm{~mL})$. The organic layers were combined, dried $\left(\mathrm{MgSO}_{4}\right)$, and filtered. The solvent was removed under reduced pressure and the product was recrystallised from DCM/pentane to give a pale straw-coloured amorphous solid; yield: $241.3 \mathrm{mg}$ (65\%).

IR (ATR, neat): 3069, 2936, 2816, 1690, 1603, $1452 \mathrm{~cm}^{-1}$.

${ }^{1} \mathrm{H}$ NMR $\left(\mathrm{CD}_{3} \mathrm{CN}, 400 \mathrm{MHz}\right): \delta=8.14(\mathrm{~s}, 1 \mathrm{H}, \mathrm{CHNOMe}), 7.64-7.61(\mathrm{~m}$, $2 \mathrm{H}, \mathrm{ArCH}$ ), 7.44-7.43 (m, $3 \mathrm{H}, \mathrm{Ar} \mathrm{CH}), 3.95\left(\mathrm{~s}, 3 \mathrm{H}, \mathrm{CH}_{3}\right)$.

${ }^{13} \mathrm{C}\left\{{ }^{1} \mathrm{H}\right\} \mathrm{NMR}\left(\mathrm{CD}_{3} \mathrm{CN}, 101 \mathrm{MHz}\right): \delta=148.0,129.4,129.1,128.3,126.3$, 60.9.

MS (GC-MS, EI): $m / z=135.1[\mathrm{M}]^{+}$.

Analytical data are consistent with the literature. ${ }^{38}$

\section{(Methylsulfinyl)benzene (A11)}

Thioanisole $(0.950 \mathrm{~mL}, 8.1 \mathrm{mmol})$ was added to a $100 \mathrm{~mL}$ roundbottomed flask equipped with a stirrer bar and dissolved in DCM (20 $\mathrm{mL}$ ). A solution of $m$ CPBA ( $2.084 \mathrm{~g}, 12.2 \mathrm{mmol}, 1.5$ equiv.) in DCM (10
$\mathrm{mL}$ ) was added to the solution at $0{ }^{\circ} \mathrm{C}$ over $5 \mathrm{~min}$, and the reaction mixture was stirred at r.t. for $12 \mathrm{~h}$. The reaction mixture was diluted with sat. aq $\mathrm{NaHCO}_{3}(100 \mathrm{~mL})$ and extracted with DCM $(2 \times 50 \mathrm{~mL})$. The organic layers were combined, dried $\left(\mathrm{MgSO}_{4}\right)$, and filtered. The solvent was removed under reduced pressure and the product was recrystallised from DCM/hexane to give a viscous colourless liquid; yield: $411.2 \mathrm{mg}$ (36\%).

IR (ATR, neat): 3464, 3055, 2995, 2913, 1709, 1582, $1476 \mathrm{~cm}^{-1}$.

${ }^{1} \mathrm{H} \mathrm{NMR}\left(\mathrm{CDCl}_{3}, 400 \mathrm{MHz}\right): \delta=7.52-7.50(\mathrm{~m}, 2 \mathrm{H}, \mathrm{Ar} \mathrm{CH}), 7.39-7.34$ (m, $3 \mathrm{H}, \mathrm{Ar} \mathrm{CH}), 2.57$ (s, $3 \mathrm{H}, \mathrm{CH}_{3}$ ).

${ }^{13} \mathrm{C}\left\{{ }^{1} \mathrm{H}\right\}$ NMR $\left(\mathrm{CDCl}_{3}, 101 \mathrm{MHz}\right): \delta=145.0,130.5,128.8,122.9,43.2$.

MS (GC-MS, EI): $m / z=140.0[\mathrm{M}]^{+}$.

Analytical data are consistent with the literature. ${ }^{34}$

\section{(E)-1,2-Diphenylethene (A17)}

Benzyltriphenylphosphonium chloride (3.842 g, $9.9 \mathrm{mmol}$ ) was added to a $100 \mathrm{~mL}$ round-bottomed flask equipped with a stirrer bar. A suspension of $\mathrm{LiOH} \cdot \mathrm{H}_{2} \mathrm{O}(0.557 \mathrm{~g}, 13.2 \mathrm{mmol})$ in $i-\mathrm{PrOH}(50 \mathrm{~mL})$ was added and the mixture was stirred at r.t. for $20 \mathrm{~min}$. Benzaldehyde $(0.960 \mathrm{~mL}, 9.4 \mathrm{mmol})$ was added and the reaction mixture was stirred at reflux for $16 \mathrm{~h}$. Once cooled to r.t., the reaction mixture was extracted with EtOAc $(75 \mathrm{~mL})$ and washed with brine $(75 \mathrm{~mL})$. The organic phase was dried $\left(\mathrm{MgSO}_{4}\right)$, filtered, and evaporated under reduced pressure. The product was recrystallised from EtOH to give a white powder; yield: $1.412 \mathrm{~g}(83 \%) ; 124-126^{\circ} \mathrm{C}$.

IR (ATR, neat): 3059, 3021, 1597, 1576, $1495 \mathrm{~cm}^{-1}$.

${ }^{1} \mathrm{H} \mathrm{NMR}\left(\mathrm{CDCl}_{3}, 400 \mathrm{MHz}\right): \delta=7.56(\mathrm{~d}, J=7.8 \mathrm{~Hz}, 4 \mathrm{H}, \mathrm{Ar} \mathrm{CH}), 7.40(\mathrm{t}$, $J=7.5 \mathrm{~Hz}, 4 \mathrm{H}, \mathrm{ArCH}), 7.30(\mathrm{t}, J=7.0 \mathrm{~Hz}, 2 \mathrm{H}, \mathrm{ArCH}), 7.16(\mathrm{~s}, 2 \mathrm{H}$, $\mathrm{CH}=\mathrm{CH})$.

${ }^{13} \mathrm{C}\left\{{ }^{1} \mathrm{H}\right\}$ NMR $\left(\mathrm{CDCl}_{3}, 101 \mathrm{MHz}\right): \delta=136.9,128.23,128.20,127.1$, 126.0.

MS (GC-MS, EI): $m / z=180.1[\mathrm{M}]^{+}$.

Analytical data are consistent with the literature. ${ }^{39}$

\section{Funding Information}

We thank Syngenta and the Engineering and Physical Sciences Research Council for an Industrial CASE Studentship for AKC (EP/P51066X/1), and the University of Strathclyde for a Chancellor's Fellowship for DJN (2014-18). We are grateful to the Carnegie Trust for the Universities of Scotland for a Research Incentive Grant (RIG008165).

\section{Acknowledgment}

We thank Mr. Gavin Bain, Mr. Craig Irving, Ms. Patricia Keating, and Dr. John Parkinson for assistance with technical and analytical facilities. We thank Dr. Michael Rogers for providing the benzyltriphenylphosphonium chloride used in this study. Some of the calculations in this manuscript were performed using the Archie-WEST high-performance computer based at the University of Strathclyde, and we are grateful to Mr. Jonathan Buzzard, Dr. Karina Kubiak-Ossowska, and Dr. Richard Martin for assistance with this facility. 


\section{Supporting Information}

Supporting information for this article is available online at https://doi.org/10.1055/s-0039-1690045. All data underpinning this publication are openly available from the University of Strathclyde KnowledgeBase at https://doi.org/10.15129/48cb8d5c-ea93-474a-9c7b-7f847cfdfe89.

\section{References}

(1) Negishi, E.-i. Angew. Chem. Int. Ed. 2011, 50, 6738.

(2) Suzuki, A. Angew. Chem. Int. Ed. 2011, 50, 6722.

(3) Johansson Seechurn, C. C. C.; Kitching, M. O.; Colacot, T. J.; Snieckus, V. Angew. Chem. Int. Ed. 2012, 51, 5062.

(4) Cooper, A.; Leonard, D.; Bajo, S.; Burton, P.; Nelson, D. ChemRxiv 2019, preprint; DOI 10.26434/chemrxiv.773716.v1.

(5) Tasker, S. Z.; Standley, E. A.; Jamison, T. F. Nature 2014, 509(7500), 299.

(6) Ananikov, V. P. ACS Catal. 2015, 5, 1964.

(7) Bajo, S.; Laidlaw, G.; Kennedy, A. R.; Sproules, S.; Nelson, D. J. Organometallics 2017, 36, 1662.

(8) Guard, L. M.; Mohadjer Beromi, M.; Brudvig, G. W.; Hazari, N.; Vinyard, D. J. Angew. Chem. Int. Ed. 2015, 54, 13352.

(9) Zhang, K.; Conda-Sheridan, M. R.; Cooke, S.; Louie, J. Organometallics 2011, 30, 2546.

(10) Tsou, T. T.; Kochi, J. K. J. Am. Chem. Soc. 1979, 101, 6319.

(11) Nelson, D. J.; Maseras, F. Chem. Commun. 2018, 54, 10646.

(12) Funes-Ardoiz, I.; Nelson, D. J.; Maseras, F. Chem. Eur. J. 2017, 23, 16728.

(13) West, M. J.; Watson, A. J. B. Org. Biomol. Chem. 2019, 17, 5055.

(14) Collins, K. D.; Glorius, F. Nat. Chem. 2013, 5, 597.

(15) Hansch, C.; Leo, A.; Taft, R. W. Chem. Rev. 1991, 91, 165.

(16) Portnoy, M.; Milstein, D. Organometallics 1993, 12, 1665.

(17) Christian, A. H.; Müller, P.; Monfette, S. Organometallics 2014, 33, 2134.

(18) Payard, P. A.; Perego, L. A.; Ciofini, I.; Grimaud, L. ACS Catal. 2018, 8, 4812.

(19) Strawser, D.; Karton, A.; Zenkina, O. V.; Iron, M. A.; Shimon, L. J. W.; Martin, J. M. L.; van der Boom, M. E. J. Am. Chem. Soc. 2005, $127,9322$.

(20) Zenkina, O. V.; Karton, A.; Freeman, D.; Shimon, L. J. W.; Martin, J. M. L.; van der Boom, M. E. Inorg. Chem. 2008, 47, 5114.

(21) Zenkina, O. V.; Gidron, O.; Shimon, L. J. W.; Iron, M. A.; van der Boom, M. E. Chem. Eur. J. 2015, 21, 16113.

(22) Orbach, M.; Shankar, S.; Zenkina, O. V.; Milko, P.; Diskin-Posner, Y.; van der Boom, M. E. Organometallics 2015, 34, 1098.
(23) He, W.; Patrick, B. O.; Kennepohl, P. Nat. Commun. 2018, 9, 3866.

(24) Rothstein, P. E.; Comanescu, C. C.; Iluc, V. M. Chem. Eur. J. 2017, 23, 16948.

(25) Tejel, C.; Asensio, L.; del Río, M. P.; de Bruin, B.; López, J. A.; Ciriano, M. A. Angew. Chem. Int. Ed. 2011, 50, 8839.

(26) Desnoyer, A. N.; He, W.; Behyan, S.; Chiu, W.; Love, J. A.; Kennepohl, P. Chemistry 2019, 25, 5259.

(27) He, W.; Kennepohl, P. Faraday Discuss. 2019, 220, 133.

(28) Kozuch, S.; Shaik, S. Acc. Chem. Res. 2011, 44, 101.

(29) Standley, E. A.; Smith, S. J.; Müller, P.; Jamison, T. F. Organometallics 2014, 33, 2012.

(30) McIntyre, J.; Mayoral-Soler, I.; Salvador, P.; Poater, A.; Nelson, D. J. Catal. Sci. Technol. 2018, 8, 3174.

(31) Fulmer, G. R.; Miller, A. J. M.; Sherden, N. H.; Gottlieb, H. E.; Nudelman, A.; Stoltz, B. M.; Bercaw, J. E.; Goldberg, K. I. Organometallics 2010, 29, 2176.

(32) Frisch, M. J.; Trucks, G. W.; Schlegel, H. B.; Scuseria, G. E.; Robb, M. A.; Cheeseman, J. R.; Scalmani, G.; Barone, V.; Mennucci, B.; Petersson, G. A.; Nakatsuji, H.; Caricato, M.; Li, X.; Hratchian, H. P.; Izmaylov, A. F.; Bloino, J.; Zheng, G.; Sonnenberg, J. L.; Hada, M.; Ehara, M.; Toyota, K.; Fukuda, R.; Hasegawa, J.; Ishida, M.; Nakajima, T.; Honda, Y.; Kitao, O.; Nakai, H.; Vreven, T.; Montgomery, J. A. Jr.; Peralta, J. E.; Ogliaro, F.; Bearpark, M.; Heyd, J. J.; Brothers, E.; Kudin, K. N.; Staroverov, V. N.; Kobayashi, R.; Normand, J.; Raghavachari, K.; Rendell, A.; Burant, J. C.; Iyengar, S. S.; Tomasi, J.; Cossi, M.; Rega, N.; Millam, J. M.; Klene, M.; Knox, J. E.; Cross, J. B.; Bakken, V.; Adamo, C.; Jaramillo, J.; Gomperts, R.; Stratmann, R. E.; Yazyev, O.; Austin, A. J.; Cammi, R.; Pomelli, C.; Ochterski, J. W.; Martin, R. L.; Morokuma, K.; Zakrzewski, V. G.; Voth, G. A.; Salvador, P.; Dannenberg, J. J.; Dapprich, S.; Daniels, A. D.; Farkas, Ö.; Foresman, J. B.; Ortiz, J. V.; Cioslowski, J.; Fox, D. J. Gaussian 09, Revision D.01; Gaussian, Inc: Wallingford CT, 2009.

(33) Fey, N.; Ridgway, B. M.; Jover, J.; McMullin, C. L.; Harvey, J. N. Dalton Trans. 2011, 40, 11184.

(34) Yuan, Y.; Shi, X.; Liu, W. Synlett 2011, 559.

(35) Tobisu, M.; Xu, T.; Shimasaki, T.; Chatani, N. J. Am. Chem. Soc. 2011, 133, 19505.

(36) Kim, D.-S.; Ham, J. Org. Lett. 2010, 12, 1092.

(37) Yu, D.-G.; Yu, M.; Guan, B.-T.; Li, B.-J.; Zheng, Y.; Wu, Z.-H.; Shi, Z.-J. Org. Lett. 2009, 11, 3374.

(38) Dubost, E.; Fossey, C.; Cailly, T.; Rault, S.; Fabis, F. J. Org. Chem. 2011, 76, 6414.

(39) Bandari, R.; Höche, T.; Prager, A.; Dirnberger, K.; Buchmeiser, M. R. Chem. Eur. J. 2010, 16, 4650. 